\title{
CELEBRATING THE CAREER OF DR. JOSEPH J. KEREKES - INTERNATIONALLY RENOWNED, NOVA SCOTIA LIMNOLOGIST
}

\author{
SÁNDOR FARAGO*, 1 \\ Institute of Wildlife Management and Vertebrate Zoology, \\ University of Sopron, \\ H-9400 Sopron, Bajcsy-Zs. u. 4., Hungary,
}

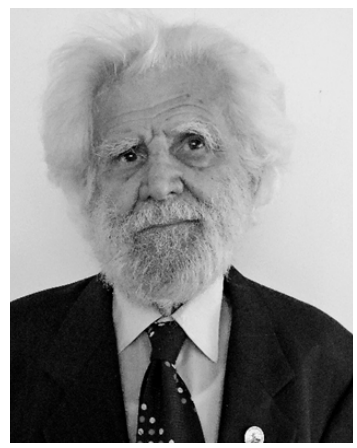

Fig 1 Dr. Joseph (“Joe") J. Kerekes, the "last limnologist", at age 85.

Over ten years ago, Dr. Joseph ("Joe") Kerekes, Emeritus Research Scientist of Environment Canada's Canadian Wildlife Service, was congratulated on his 75th birthday (Faragó 2008). Recently, we had the honour to celebrate his 85th birthday (Figure 1). He remains a member of the editorial board for Hungarian Waterfowl Publications. This Hungarian born scientist has lived in Canada since 1956, receiving his graduate degrees in Canada and spending a career as a federal government limnologist. All the while, he maintained relationships with colleagues all over the world, especially with Hungarian limnologists and waterfowl ornithologists. Burnett (1999) wrote a chapter on Joseph Kerekes with the title, "The Last Limnologist". His outstanding career in Canada, as well as his publications

Author to whom correspondence should be addressed: farago.sandor@uni-sopron.hu

1 This article was edited and adapted for the PNSIS by both Editors, PGW and DHR. Wells had the privilege of knowing "Joe" Kerekes while working with the Canadian Wildlife Service, Conservation and Protection, Environment Canada, Dartmouth, NS. They currently work together on Bay of Fundy issues and share a deep interest in the waters and wildlife of "Keji" (Kejimkujik National Park). 
(see below and Farago 2008), show what an inspiration he should be to the younger generation of limnologists and ornithologists.

In Atlantic Canada, the shift towards pure limnology was actively encouraged by Jean-Paul Cuerrier who recruited Joseph Kerekes, then a graduate student at the University of Alberta in 1965. Kerekes had become "indoctrinated" (his word) at the University of Alberta in the virtues of the Wildlife Service by Bill Fuller, who was teaching a graduate seminar in wildlife management. In December, 1965, while attending a conference in Montreal, Kerekes was approached by John Tener said "if I wanted a job I should call Jean-Paul Cuerrier in Ottawa.So I did, and the first question Cuerrier asked me was whether I had any furniture that had to be moved. Well, a poor student just graduated sure didn't have furniture to worry about. That was in the good old days when there was expansion and people could make real decisions, just like that! The Park Service expected I would be another trout biologist, but the job title was limnologist, so I took it literally and practised limnology" (Kerekes 1997).

Terra Nova National Park, in eastern Newfoundland, had been established in 1957, only eight years prior to Joseph Kerekes's appointment. He responded enthusiastically to the suggestion that he concentrate his efforts there. Starting in 1967, he began an inventory of all the water bodies in Terra Nova. Of those, he selected four for closer investigation of their productive capacity. This entailed monitoring the growth rates and feeding habits of Brook Trout (Salvelinus fontinalis Mitchill) and attempting, from this information, to estimate the total biomass and sustainable yield of these populations. As part of his analysis of the Terra Nova lakes, Kerekes had routinely measured total phosphorus and chlorophyll in water samples. He was struck by the correlation between the two and became one of the very first limnologists anywhere to appreciate the importance of phosphorus in the productivity of inland waters (i.e., lakes and rivers). This marked a departure from conventional park fisheries management. It led to research in a new area, resulting eventually in his Ph.D. (Dalhousie University) and a new and highly original dimension of limnological studies and environmental monitoring.

Kerekes'work attracted international attention. He was invited to participate in an OECD (Organisation for Economic Co-operation and Development) program on eutrophication. This involved studies of 128 lakes in 18 countries. In the late 1970s, he was seconded to the OECD for two years to work as coauthor of a report on these studies. 
This would eventually play a key role in accomplishing the widespread banning of phosphate detergents (Vollenweider and Kerekes 1980).

Around this time, the Canadian Wildlife Service (CWS) of Environment Canada undertook the task of assessing the wildlife resources in Canada's national parks. Kerekes was assigned to coordinate the work on aquatic resources. Kejimkujik National Park, in southwest Nova Scotia, was one of the first parks to be surveyed (Kerekes 1992). It was a fortunate choice. Most of the lakes in the park are naturally acidic. Kerekes was intrigued by the question of how acidic deposition ("acid rain") would influence them. In 1977, he put forward a proposal to investigate the long-range transport of air pollutants and their deposition in the Kejimkujik lakes (Kerekes 1977). His international reputation from his OECD experience probably aided the proposal's ultimate approval, in spite of the fact that the initial reaction at CWS headquarters was less than enthusiastic.

At first, people dismissed my proposal. I was told that I shouldn't study acid rain there because the amount was immeasurably small. Others said, "The acid is from organic sources, don't bother about it." I was even told that you couldn't study birds in Kejimkujik because the population density was too low. But I have to admit that I went and started working in a small way anyway. Eventually, in 1980, the proposal came to the attention of the national acid rain coordinating people and they liked it, so I was asked to do it officially. I worked on it then until 1983, when the Inland Waters Directorate came in with their own people to work on water quality (Kerekes 1997).

The study showed that highly sensitive, naturally acidic lakes such as the ones in Kejimkujik were affected even by minimal inputs of acid precipitation from distant sources. It was that sensitivity that won international recognition for the park as a very special site for the monitoring of environmental quality (Vollenweider and Kerekes 1980). Thanks in large part to the acid rain study, the park eventually became the prototype site for Canada's national Environmental Monitoring and Assessment Network (EMAN).

When the Inland Waters Directorate, Environment Canada, assumed an active role at the park, Kerekes turned to other tasks. He took part in the CWS Latin American Program, first in Brazil and later in Mexico, where he evaluated the productivity of lagoons and lakes in the states of Oaxaca and Chiapas. Only in 1988 did he return to the study of aquatic invertebrates, fish, and fish-eating birds in Kejimkujik National Park. This brought him in a full circle, back to 
the early work in Terra Nova. Once again, he found himself looking at phosphorus as the determining factor to the abundance of plankton, fish and, by extension, fish-eating birds (Fig 2). The Kejimkujik findings were among topics highlighted in an international symposium on aquatic birds and limnology that was organized in Sackville, New Brunswick, in 1991 (Kerekes 1994). The interest expressed at that event moved him to establish an international working group on aquatic birds, which has subsequently held workshops in Hungary, Canada, Spain, Sweden and the Yucatan, Mexico.

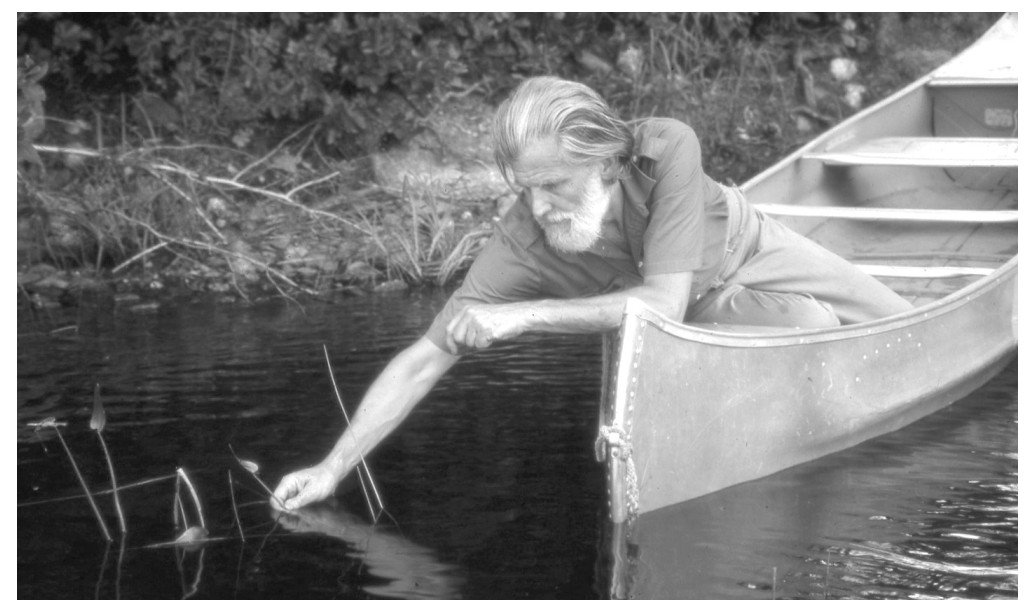

Fig 2 Joe Kerekes investigating aquatic vegetation in Kejimkujik National Park, NS, 30-35 years ago. (picture by Eric Mullen, Parks Canada).

Kerekes retired in 1996, with an inescapable feeling that limnology in Environment Canada (CWS) had retired with him. In an interview in 1997, he reminisced:

Back in the 1970s, Canada was on the cutting edge of limnology on a world-wide scale. If you came from Canada, people paid attention. Nowadays, it's neither here nor there. Today, it might be impossible to start the Keji (Kejimkujik) study. Of course, there's still water quality work going on, but that's not limnology. The fishery is one part of the lake. The water quality is another. It takes the holistic view of the limnologist to integrate them. But nowadays, everyone is backing away from that generalized work. The federal departments say it's not in their mandate. The provinces say they have no money. And so a lot of good research, in areas that are not clearly defined by legislation and regulation, is just being abandoned. 
I was really lucky to be working when I did. I used to say, back then "The good old days are happening right now." And I was right.

At the time of his retirement, Kerekes received a Scientific Emeritus appointment with CWS that he kept until 2014. He continues to work, being directly involved with the annual loon (Gavia immer) survey in Kejimkujik National Park and serving on the steering committee of the Bay of Fundy Ecosystem Partnership (Wells, pers.comm.). On the occasion of his $85^{\text {th }}$ birthday, everyone wished him many more birthdays and celebrated his career as one of Canada's outstanding aquatic scientists. One fervently hopes that he will not be one of "the last limnologists" in Nova Scotia and the Maritime Region, so filled with streams, rivers, ponds and lakes requiring continued research, monitoring and management.

\section{REFERENCES}

Burnett, J.A. (1999). A Passion for Wildlife. A History of the Canadian Wildlife Service, 1947-1997 and Selected Publications from Work by the Canadian Wildlife Service. Field-Naturalist 113(1): 1-183.

Farago, S. (2008). A 75 éves Dr. Kerekes József köszöntése (Welcoming of 75-year-old Dr. Joseph Kerekes). Magyar Vizivad Közlemények Hungarian Waterfowl Publications 16: 1-20.

Kerekes, J.J. (1992). Aquatic research and long term monitoring in Atlantic Canada's National Parks. In Willison, J.H.M., Bondrup-Nielsen, S., Drysdale, C., Herman, T.B., Munro, N.W.P., \& Pollock, T.L. (eds). Science and the Management of Protected Areas: Proceedings of an International Conference, held at Acadia University, Wolfwille, Nova Scotia, 14-19 May 1991, organized by the Science and Protected Areas Association. Amsterdam: Elsevier Publishing).

Kerekes, J.J. (1994). Long range transport of air pollutants - a research proposal (Ottawa: Environment Canada, Canadian Wildlife Service, 1977; reprinted December 1994).

Kerekes, J.J. (1997). Personal communication, interviewed at Dartmouth, Nova Scotia, 26 March 1997.

Kerekes, J.J., \& Pollard, B. (eds.). Aquatic Birds in the Trophic Web of Lakes: Proceedings of a Symposium Held in Sackville, New Brunswick, Canada, in August 1991. (Dordrecht, The Netherlands: Kluwer Academic Publishers, 1994: reprinted from Hydrobiologia 279/280: 207-221, 1994).

Vollenweider, R.A., \& Kerekes, J.J.(1980). Synthesis Report. Cooperative Programme on Monitoring of Inland Waters (Eutrophication Control). Report prepared on behalf of the Technical Bureau, Water Management Sector Group, Organisation for Economic Co-operation and Development, Paris. 


\section{JOSEPH J. KEREKES: PUBLICATIONS SINCE 2006}

Andrikovics,S.,Forró,L., \& Kerekes,J.J.(2008). Preface.Acta Zoologica Academiae Hungaricae 54 Suppl. 1: 3-6.

Andrikovics, S., Forró, L., \& Kerekes, J.J. (2008). Proceedings. "Limnology and Waterbirds 2006" - Conference of Working Group on Aquatic Birds of the International Society of Limnology. Eger, Hungary, August 26-30. 2006. Acta Zoologica Academiae Hungaricae 54. Suppl. $1,269 \mathrm{p}$.

Andrikovics, S., Kerekes, J.J., Kriska, Gy., \& Liszi, J. (2003). Limnológiai alapismeretek (Introduction to Limnology). EKF Líceum Publ. Eger, Hungary (in Hungarian.), 254 p.

Faragó, S., \& Kerekes, J. J. (2006). Water quality monitoring in the Hungarian waterbird monitoring system. In: Hanson, A., Kerekes, J. \& Paquet, J. (eds.): Limnology and Aquatic Birds: Abstracts and Selected Papers from the Fourth Conference of the Societas Internationalis Limnologiae (SIL) Aquatic Birds Working Group. Canadian Wildlife Service Technical Report Series No. 474, Atlantic Region.

Gór, D., Lakatos, G., Szilágyi, E., Andrikovics, S., \& Kerekes, J.J. (2007). Study on macrophytic communities and waterbirds in the function of Kiskörei Reservoir (Eastern Hungary). Verhandlungen des Internationalen Verein Limnologie. 30: 1088-1090.

Hanson, A., Kerekes, J.J., \& Paquet, J. (2006). (eds). Limnology and Aquatic Birds: Abstracts and Selected Papers from the Fourth Conference of the Societas Internationalis Limnologiae (SIL) Aquatic Birds Working Group. Canadian Wildlife Service Technical Report Series No. 474. Atlantic Region. xii + 203 p. www.briloon.org/science-andconservation/centers/DLSG.php

Kerekes, J.J. (2007). Aquatic Birds Working Group of the International Society of Limnology. SIL News 50: 11.

Kerekes, J.J. (2008a). In memoriam Sándor Andrikovics. Acta Zoologica Academiae Hungaricae 54. Suppl. 1: 1-2.

Kerekes, J.J. (2008b). Habitat use by breeding loons in Atlantic Canada. Acta Zoologica Academiae Hungaricae 54 Suppl. 1: 265-269.

Kerekes, J.J., Hope, P., McCarthy, C., \& O’Grady, S. (2008). Long term monitoring of the common loon (Gavia immer) population on 18 lakes in Kejimkujik National Park, Nova Scotia, Canada since 1988. Verhandlungen des Internationalen Verein Limnologie. 30 (5): 705-708. 